\title{
Modeling, Analysis and Optimization for the Biodiesel Production Process from Waste Cooking Oil
}

\author{
Walaa Mahmoud Shehata, Ahmad Mohamed Mokhtar
}

\begin{abstract}
The present study proposed a rigorous model using detailed kinetics reaction for the alkali transesterification of waste cooking oil with methanol and Alkali Catalyst (NaOH). Aspen Plus software is used. The results showed that the rigorousness of the model helps in predicting more realism and accurate result. The effect of different parameters on the process like temperature, pressure, residence time, methanol to oil ratio, and catalyst $(\mathrm{NaOH})$ weight percentage were studied. All the studied parameters have significant effect on the process performance except pressure. Optimization of the process also carried out to find the best conditions for maximum profit and maximum production. The optimization results showed that the reaction temperature decreased from 60 to $45{ }^{\circ} \mathrm{C}$, the reaction time decreased from 60 to 49 minutes, the molar ratio of methanol/oil increased from 6:1 to 7.2:1 mole ratio and the catalytic concentration decreased from 1 to $0.25 \mathrm{wt} \%$.
\end{abstract}

Keywords: Biodiesel, transesterification, Waste Cooking Oil, Aspen Plus.

\section{INTRODUCTION}

Biodiesel as an alternative fuel option is a high priority for scientists 'research, even in periods when the price of oil is low, as there are large predictions of the end of the fossil fuel era from non-renewable resources. Alkali transesterification of vegetable oils is the main process used commercially for the biodiesel production, and using waste cooking oil overcomes the issue of high feedstock prices and helps in solving the waste oil treatment process. Biodiesel is considered as a renewable and clean-burning diesel replacement. It can be used in existing diesel engines without any modification as it meets the technical fuel quality and engine performance specifications. It is covered by all major engine manufacturers' warranties, most often in blends of up to 5 percent or 20 percent biodiesel [1].

According to the American Society for Testing and Materials (ASTM), biodiesel is a fuel composed of mono-alkyl esters of long chain fatty acid methyl esters (FAME) derived from vegetable oils or animal fats, designated B100 [2].

Revised Manuscript Received on February 05, 2020.

* Correspondence Author

Walaa M. Shehata*, Petroleum Refining and Petrochemical Engineering, Suez University, Faculty of Petroleum and Mining Engineering, Suez, Egypt. E-mail: walaashahata78@yahoo.com

Ahmed M. Mokhtar, Department of Technology and Development. Nasr Petroleum Company, Suez, Egypt.

E-mail: ahmadmmokhtar@gmail.com

(c) The Authors. Published by Blue Eyes Intelligence Engineering and Sciences Publication (BEIESP). This is an open access article under the CC BY-NC-ND license (http://creativecommons.org/licenses/by-nc-nd/4.0/)

Advantages of biodiesel over petrol-diesel are its renewability and low emission profile of carbon monoxide, sulphur compounds, particulate matter and unburned hydrocarbon [3]. It has relatively higher combustion efficiency and higher

cetane number $[4,5]$. Also, biodiesel has a higher flash point which makes it safer to transport and handle [6].

Biodiesel is made through a chemical process called transesterification reaction. This transesterification reaction can be alkali-, acid-, or enzyme-catalyzed. It also can take place without the use of a catalyst under the supercritical conditions of the alcohol [7, 8]. However, among all systems of biodiesel production, the alkali-catalyzed process is the most widely used in current commercial biodiesel plants [9]. Vegetable oil is expressed chemically as triglyceride or triacylglycerol. In the transesterification reaction, triglyceride reacts with an alcohol in the presence of a catalyst, to produce alkyl esters and glycerol. Methanol, ethanol and butanol are the recommended alcohols [10], but methanol is the most favorable and commonly used alcohol due to its lower price. The resulting esters are called fatty acid methyl esters (i.e., FAME or biodiesel). Sodium hydroxide and potassium hydroxide are the commonly used alkali catalysts.

Virgin vegetable oils are the main feedstock for biodiesel, but it is reported that the high cost of biodiesel is mainly due to the cost of virgin vegetable oils $[6,11]$. Therefore, using a cheaper alternative feedstock is considered a primary solution to lower the production cost. Waste cooking oil (WCO) is the best alternative feedstock as it is estimated to be about half the price of virgin vegetable oil [12]. It also helps to solve the problem of waste oil disposal [13].

For the alkali-catalyzed process, the reaction conditions are a temperature near the boiling point of the alcohol (e.g., $60^{\circ} \mathrm{C}$ for methanol) and a $6: 1$ molar ratio of alcohol to oil $[10,14]$. Studies of the kinetics of the alkali-catalyzed system by Noureddini and Zhu [14] and Darnoko and Cheryan [15] showed that approximately 90-98\% oil conversion to methyl esters was observed within $90 \mathrm{~min}$.

The presence of water in the system may cause ester saponification in alkaline conditions [16, 17]. Also, the alkaline catalyst is very sensitive to free fatty acid in the biodiesel feedstock. Where free fatty acid can react with the alkaline catalyst to produce soap and water Thus, dehydrated vegetable oil with less than 0.5 wt.\% free fatty acids, an anhydrous alkali catalyst and anhydrous alcohol are recommended for commercially viable alkali-catalyzed systems $[10,18]$. 
As the level of free fatty acids in waste cooking oil is greater than 2 wt.\% [19, 20] so, for alkali-catalyzed process, a pretreatment step is required to reduce the free fatty acid content via esterification reaction with methanol in the presence of sulfuric acid catalyst [19].

Presently, a number of biodiesel processes have been developed.

Zhang et al. [21] developed a HYSYS-based process simulation model to assess the technological feasibility of four biodiesel plant configurations (alkali and acid catalyst with both virgin oil and waste oil). All the four models were simulated as conversion reaction according to the data given by Freedman et al.[10] and Noureddini and Zhu [14]. West et al. [22] developed a process flowsheets for the biodiesel production from waste cooking oil using alkali, acid, heterogeneous catalyst and supercritical process. All the models were assumed to be conversion reactions. Marchetti et al. [23] introduced a techno-economic study for a two-stage transesterification process with alkali, acid, heterogeneous catalyst. They found that, the alkali catalyst process was the lowest cost per kilogram of product.

Most previous developed models have lack in the kinetic reaction information and/or unavailability of some components of the oil in simulator databank. They used a single component (Triolein) to represent the vegetable oil and a single fatty acid methyl ester (Methyl Oleate) to represent biodiesel product. Besides, the conversion percent of feedstock is assumed to model the transesterification reaction based on published literatures. Those earlier models provided a useful preliminary description of the biodiesel production process and a preliminary comparison of process parameters and modifications for biodiesel production.

The objective of this study is to develop a rigorous process model for biodiesel production from waste cooking oil using alkali catalyst with a pre-treatment unit using Aspen Plus simulation software. The advantage of the new biodiesel databank available in Aspen properties in Aspen Plus which offers physical properties of triglycerides, diglycerides and monoglycerides, combined with the detailed kinetic data for the reaction from Narvaez et al. [24] has been taken. Also, the update electrolyte components in Aspen Plus helps to behave better when this model is extended and gives more accurate results specially within the separation processes. This new model will have a detailed kinetic model for transesterification, and it can be used to study the effect of different parameters on the process. In addition, the optimization tools are used to find out the best design and operation conditions. Moreover, the quality of biodiesels as measured by properties such as density, kinematic viscosity and cetane number, can be evaluated according to the predicted composition profile of methyl fatty acid esters.

\section{DESIGN METHODOLOGY}

The biodiesel production process used in this work (Fig. 1) is based on the biodiesel production process developed by Zhang et al. [21] with some modifications as following:

- Using actual composition of oil, and actual kinetic parameters for the reactions as presented in Tables I, II and III.

- Washing towers (Liquid-Liquid extractors) are configured for actual separation instead of component splitter which gave theoretical perfect separation.

- Recycling of the glycerol produced to be used in the pre-treatment washing column.

- Recycling of the unreacted oil to transesterification reactor again.

Process feedstock is waste cooking oil (WCO). It is composed of triglyceride, diglyceride and free fatty acid. The triglyceride is classified as triunsaturated, monosaturated, disaturated and trisaturated triglyceride. On the other hand, diglyceride is presented as 1,3 dipalmitin (PP) [25]. It is assumed that the WCO has 6 wt.\%. of free fatty acids (FFA). Using actual composition of virgin palm oil determined by Che Man [26], then a 6 wt.\%. of free fatty acid (Oleic Acid) is added. The total composition percent re-normalized to represent the waste cooking oil (WCO) (Table I).

Table I: Composition of waste cooking oil (WCO)

\begin{tabular}{|c|c|c|c|}
\hline Component & Name & Structure & $\begin{array}{l}\text { Mass } \\
\text { Fraction }\end{array}$ \\
\hline $\mathrm{OOO}$ & $\begin{array}{c}\text { Triolein } \\
\text { (Triunsaturated } \\
\text { Triglyceride) }\end{array}$ & C57H104O6 & 0.041 \\
\hline OOLI & $\begin{array}{l}\text { TAG-OOLI } \\
\text { (Triunsaturated } \\
\text { Triglyceride) }\end{array}$ & C57H102O6-5 & 0.005 \\
\hline PLIO & $\begin{array}{l}\text { TAG-PLIO } \\
\text { (Monosaturated } \\
\text { Triglyceride) }\end{array}$ & C55H100O6-7 & 0.091 \\
\hline POO & $\begin{array}{c}\text { TAG-POO } \\
\text { (Monosaturated } \\
\text { Triglyceride) }\end{array}$ & C55H102O6-6 & 0.219 \\
\hline OOS & $\begin{array}{c}\text { TAG-OOS } \\
\text { (Monosaturated } \\
\text { Tridera) }\end{array}$ & C57H106O6-4 & 0.021 \\
\hline MPLI & $\begin{array}{l}\text { TAG-MPLI } \\
\text { (Disaturated } \\
\text { Triglyceride) }\end{array}$ & C51H94O6-3 & 0.021 \\
\hline PPLI & $\begin{array}{l}\text { TAG-PLIP } \\
\text { (Disaturated } \\
\text { Triglyceride) }\end{array}$ & C53H98O6-5 & 0.087 \\
\hline PPO & $\begin{array}{l}\text { TAG-POP } \\
\text { (Disaturated } \\
\text { Triglyceride) }\end{array}$ & C53H100O6-5 & 0.278 \\
\hline POS & $\begin{array}{l}\text { TAG-POS } \\
\text { (Disaturated } \\
\text { Triglyceride) }\end{array}$ & C55H104O6-3 & 0.046 \\
\hline MMM & $\begin{array}{l}\text { TRIMYRISTIN } \\
\text { (Trisaturated } \\
\text { Triglyceride) }\end{array}$ & C45H86O6 & 0.004 \\
\hline MMP & $\begin{array}{l}\text { TAG-MMP } \\
\text { (Trisaturated } \\
\text { Triglyceride) }\end{array}$ & C47H90O6-10 & 0.016 \\
\hline РPP & $\begin{array}{c}\text { TRIPALMITIN } \\
\text { (Trisaturated } \\
\text { Triglyceride) } \\
\end{array}$ & C51H98O6 & 0.052 \\
\hline PPS & $\begin{array}{l}\text { TAG-PPS } \\
\text { (Trisaturated } \\
\text { Triglyceride) }\end{array}$ & С53H102O6-13 & 0.010 \\
\hline
\end{tabular}




\begin{tabular}{|c|c|c|c|}
\hline PP & $\begin{array}{c}\text { 1,3 DIPALMITIN } \\
\text { (Diglyceride) }\end{array}$ & C35H68O5-1 & 0.049 \\
\hline FFA & $\begin{array}{c}\text { Oleic Acid (Free } \\
\text { fatty acids) }\end{array}$ & C18H34O2 & 0.060 \\
\hline
\end{tabular}

The biodiesel production process from waste cooking oil consists of two steps; first step is the pre-treatment process in which the FFA is converted to fatty acid methyl ester according to the esterification reaction presented in Equation 1 using sulfuric acid as catalyst [27].

$$
\begin{gathered}
\mathrm{R}-\mathrm{COOH}(\text { oleic acid })+\mathrm{CH}_{3}-\mathrm{OH} \stackrel{\mathrm{K1}}{\stackrel{\mathrm{K} 2}{\longleftrightarrow}} \mathrm{R}-\mathrm{COO} \\
-\mathrm{CH}_{3} \\
+\mathrm{H}_{2} \mathrm{O}
\end{gathered}
$$

Where $\mathrm{R}$ is a linear chain of $11-17$ carbon atoms.

In this reaction the free fatty acid feed is esterificated with methanol $\left(\mathrm{CH}_{3}-\mathrm{OH}\right)$ in presence of acid catalyst $\left(\mathrm{H}_{2} \mathrm{SO}_{4}\right)$ to produce fatty acid methyl esters $\left(\mathrm{R}-\mathrm{COO}-\mathrm{CH}_{3}\right)$ and water.

Kinetic parameters for the esterification reaction in the pre-treatment step are taken from M. Berrios et al. [27]. The rate of reaction is presented as first order in the forward direction and second order in the reverse direction as presented in Equation 2.

\section{$r_{A}$}

$=K_{1}[A]-K_{2}[B][C]$

Where $[A]$ is the concentration of free fatty acid in $\mathrm{mg}$ $\mathrm{H}_{2} \mathrm{SO}_{4} / \mathrm{g}$ oil which is defined as the acid value; $[B]$ and $[C]$ are concentrations of the fatty acid methyl esters and the water, respectively, that formed during the reaction; $K_{1}$ and $K_{2}$ are the kinetic constants for the forward and the reverse reaction respectively, can be calculated using Equation 3 and Table II.

$$
K_{n}=a \cdot \exp \left[\frac{-\Delta E}{R \cdot T}\right]
$$

Where $\mathrm{n}$ is the reaction number; $\mathrm{a}$ and $-\Delta E$ are the pre-frequency factor and the activation energy, respectively, calculated as presented in Table II. $\mathrm{R}$ is the universal gas constant; $\mathrm{T}$ is the reaction temperature.

Table II Kinetic Parameters for the esterification of FFA in the pre-treatment step

\begin{tabular}{|c|c|c|}
\hline & $\begin{array}{c}\text { Pre-exponential } \\
\text { factor }(\mathrm{a})\end{array}$ & $\begin{array}{c}\text { Activation Energy } \\
(-\Delta \mathrm{E}) \mathrm{kJ} / \mathrm{mol}\end{array}$ \\
\hline $\begin{array}{c}\text { Forward } \\
\text { reaction }\left(\mathrm{K}_{1}\right)\end{array}$ & $2.869 \mathrm{e}+06$ & 50.745 \\
\hline $\begin{array}{c}\text { Reverse } \\
\text { reaction }\left(\mathrm{K}_{2}\right)\end{array}$ & 37.068 & 31.0073 \\
\hline
\end{tabular}

The second step in the biodiesel production process is the transesterification of the other components of the WCO after the pre-treatment process. kinetic parameters for the transesterification reactions are taken from Narvaez et al. [24] with the modification and conversion from Aspentech [25] to add the concentration of catalyst $(\mathrm{NaOH})$ into the kinetics.

The rate of transesterification reaction is presented in following Equation 4 [25]:
$r=K_{n} \exp \left[-\frac{\Delta E}{R T}\right] \prod_{i=1}^{N} C_{i}^{\mathrm{ai}}\left[\frac{1}{T}-\frac{1}{T_{o}}\right]$

Where $T_{o}$ is the reference temperature; $\mathrm{N}$ is number of components in the reaction; $C_{i}$ is concentration of component $i$; ai is the stoichiometric coefficient of component $i$ in the reaction equation; $\mathrm{E}$ is the activation energy; and $\mathrm{R}$ is the universal gas constant. Table III illustrates the different transesterification reactions with pre-exponential factor and the activation energy required for the second step of the biodiesel production process.

Note that the diglycerides in the feed (WCO) are presented in this work as 1,3- DIPALMITIN (PP). The diglycerides (DG) like 1,3-DIMYRISTIN (MM), 1,3-DIOLEIN (OO), SN-1-PALMITO-3-LINOLEIN (PLI) and SN-1-MYRISTO-3-PALMITIN (MP), in addition to the monoglycerides (MG) like 1-MONOMYRISTIN (1-M), 1-MONOPALMITIN (1-P), 1-MONOSIEARIN (1-S), MONOOLEIN (1-O) and 1-MONOLINOLEIN (1-LI) are formed in the reactions as intermediates.

The biodiesel products are all the methyl esters produced from the reaction as Methyl-Oleate, Methyl-Stearate, Methyl-Linoleate, Methyl-Palmitate and Methyl-Myristate. The catalyst sodium hydroxide used in the reaction is removed at the end of the reaction by adding $\mathrm{H}_{3} \mathrm{PO}_{4}$ to precipitate $\mathrm{Na}_{3} \mathrm{PO}_{4}$.

The reactions presented in Table III follow the kinetics presented in Equation 5. Where the biodiesel transesterification reaction consists of three-steps.

The first step is the transesterification of triglyceride into diglyceride, then, the diglyceride reacts with methanol to produce the monoglyceride, after that, the monoglyceride reacts with methanol to produce the methyl esters and the Glycerol.

Note that each reaction of the previous reactions can be processed in the reverse reaction.

Triglyceride $(\mathrm{TG})+\mathrm{CH}_{3} \mathrm{OH}$

$\Longleftrightarrow$ Diglyceride $(D G)+\mathrm{RCOOCH}_{3}$

Diglyceride (DG) $+\mathrm{CH}_{3} \mathrm{OH}$

$\Longleftrightarrow$ Monoglyceride (MG) + RCOOCH

Monoglyceride (MG) $+\mathrm{CH}_{3} \mathrm{OH}$

$$
\Longleftrightarrow \text { Glycerol }+\mathrm{RCOOCH}_{3}
$$

The property method used in this work for the biodiesel model is UNIQ-RK which is the UNIQUAC activity model with Redlich-Kwong equation of state with Henry's law. The UNIQUAC model can describe strongly non ideal liquid solutions and liquid-liquid equilibria. The UNIQ-RK property method uses the UNIQUAC activity coefficient model for the liquid phase, the Redlich-Kwong equation of state for the vapor phase, the Rackett model for liquid molar volume and Henry's law for supercritical components. This is suitable for preliminary work. Thermophysical property model parameters of tri-, di-, and mono-glycerides are currently available in the new biodiesel databank in Aspen Plus. 
It includes vapor pressure, heat of vaporization, ideal gas heat of formation, ideal gas heat capacity, liquid heat capacity, liquid molar volume and liquid viscosity. In addition, the required critical temperature $\left(\mathrm{T}_{\mathrm{C}}\right)$, critical pressure $\left(\mathrm{P}_{\mathrm{C}}\right)$ and OMEGA for Redlich-Kwong-Soave equation of state (EOS) used to model vapor phase properties are estimated with the Gani group contribution method.

Table III: Transesterification reactions in the

\begin{tabular}{|c|c|c|c|c|c|}
\hline Peaction & $\begin{array}{l}\text { Pre-expone } \\
\text { ntial facior } \\
\text { (a) }\end{array}$ & $\begin{array}{l}\text { Activation } \\
\text { Encrgy AI } \\
\text { (kcalimol) }\end{array}$ & Reaction & $\begin{array}{l}\text { Preespone } \\
\text { mial factor } \\
\text { (a) }\end{array}$ & $\begin{array}{l}\text { Activation } \\
\text { Encrgy } \Delta E \\
\text { (kcalimol) }\end{array}$ \\
\hline$O O O+$ Methanal $\stackrel{X_{3}}{\longrightarrow}$ Methyl $-O+O O$ & 002311 & 135 & $P L I+$ Methanol $\stackrel{N_{51}}{\longrightarrow}$ Methyl $-L I+1-P$ & 0.05330 & 17.4 \\
\hline $00+$ Methyl $-0 \stackrel{K_{4}}{\longrightarrow} 000+$ Methanol & 0.001867 & 103 & Methyl $-L I+1-P \stackrel{K_{13}}{\longrightarrow} P L I+$ Methanol & 0.002217 & 162 \\
\hline $00+$ Methanol $\stackrel{M}{\rightarrow}$ Methyl $-0+1-O$ & 0.10699 & 17.4 & $P L f+$ Methanal $\stackrel{N_{33}}{\rightarrow}$ Methyl $-P+1-L I$ & 0.05330 & 17.4 \\
\hline Methyl $-0+1-0 \stackrel{K_{6}}{\rightarrow} 00+$ Methanal & 0.002217 & 162 & Methyl $-P+1-L f \stackrel{N_{54}}{\longrightarrow}$ Methanal $+P L I$ & 0.002217 & 16.2 \\
\hline $1-O+$ Methanol $\stackrel{K_{7}}{\rightarrow}$ Methyl $-O+$ Glyceral & 0.05754 & 6.2 & $1-L I+$ Methanal $\stackrel{N_{s s}}{\longrightarrow}$ Methyl $-L I$ & 0.05754 & 62 \\
\hline Methyl $-O+$ Glycerol $\stackrel{K_{5}}{\longrightarrow}$ Methanal $+1-0$ & 0.000267 & 11.9 & Methyl $-L I+$ Glycerol $\stackrel{K_{36}}{\longrightarrow} 1-L I$ & $0.00<267$ & 11.9 \\
\hline MMM + Methanol $\stackrel{K_{0}}{\rightarrow}$ Methyl $-M+M M$ & 002311 & 135 & $P O O+$ Methanol $\stackrel{\mathrm{X}_{\mathrm{g}}}{\rightarrow}$ Methyl $-O+P O$ & 0.01541 & 135 \\
\hline Methyl - M + MM $\stackrel{N_{10}}{\longrightarrow}$ MMM + Methanol & 0.001867 & 103 & Methyl $-O+P O \stackrel{X_{2}}{\longrightarrow} P O O+$ Methanol & 0.001867 & 103 \\
\hline$M M+$ Methanal $\stackrel{N_{11}}{\longrightarrow}$ Methyl $-M+1-M$ & 0.10659 & 17.4 & $P O O+$ Methanol $\stackrel{X_{m}}{\longrightarrow}$ Methyl $-P+O O$ & 0.00770 & 13.5 \\
\hline Methyl $-M+1-M \stackrel{K_{\mathrm{D}}}{\longrightarrow} M M+$ Methanol & 0.002217 & 162 & Methyl $-P+O O \stackrel{K_{\infty}}{\longrightarrow}$ Methanal + POO & 0.001867 & 103 \\
\hline $1-M+$ Methanol $\stackrel{R_{D}}{\longrightarrow}$ Methyl $-M+$ Glycerol & 0.05754 & 62 & POS + Methanol $\stackrel{N_{a}}{\longrightarrow}$ Methyl $-S+P O$ & 0.00770 & 135 \\
\hline Methyl $-M+$ Glyceral $\stackrel{X_{3}}{\longrightarrow}$ Methanal $+1-M$ & 0.000267 & 11.9 & Methyl $-S+P O \stackrel{X_{Q}}{\longrightarrow}$ Methanal $+P O S$ & 0.001867 & 103 \\
\hline$P P P+$ Metharol $\stackrel{K_{13}}{\longrightarrow}$ Methyl $-P+P P$ & 0.02311 & 13.5 & POS + Metharol $\stackrel{K_{a}}{\longrightarrow}$ Methyl $-P+$ as & 0.00770 & 13.5 \\
\hline Methyl $-P+P P \stackrel{K_{16}}{\longrightarrow} P P P+$ Methanol & 0.001867 & 103 & Methyl $-P+O S \stackrel{K_{4}}{\longrightarrow} P O S+$ Methanol & 0.001867 & 103 \\
\hline 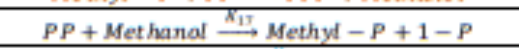 & 0.10659 & 17.4 & POS + Methanol $\stackrel{X_{G}}{\longrightarrow}$ Methyl $-O+P S$ & 0.00770 & 135 \\
\hline Methyl $-P+1-P \stackrel{K_{\mathrm{E}}}{\longrightarrow}$ Metharal $+P P$ & 0.002217 & 16.2 & Methyl $-O+P S \stackrel{K_{\infty}}{\longrightarrow} P O S+$ Metharol & 0.001867 & 10.3 \\
\hline $1-P+$ Methanol $\stackrel{R_{w}}{\longrightarrow}$ Methyl $-P+$ Glycerol & 0.05754 & 62 & PLIO + Methanol $\stackrel{X_{e}}{\longrightarrow}$ Methyl $-O+P L I$ & 0.00770 & 135 \\
\hline Methyl $-P+$ Glyceral $\stackrel{N_{30}}{\longrightarrow}$ Methanal $+1-P$ & 0000267 & 11.9 & Methyl $-O+P L I \stackrel{X_{\sigma}}{\longrightarrow} P L I O+$ Methanol & 0.001867 & 103 \\
\hline$P P S+$ Methanol $\stackrel{N_{21}}{\longrightarrow}$ Methyl $-S+P P$ & 0.00770 & 135 & PLIO + Methanol $\stackrel{N_{\infty}}{\longrightarrow}$ Methyl $-P+L I O$ & 0.00770 & 135 \\
\hline Methyl $-S+P P \stackrel{X_{23}}{\longrightarrow}$ Methanol + PPS & 0.001867 & 103 & Methyl $-P+$ LIO $\stackrel{X_{\mathrm{m}}}{\longrightarrow} \mathrm{PLIO}+$ Methanol & 0.001867 & 103 \\
\hline PPS + Methanol $\stackrel{X_{M}}{\rightarrow}$ Methyl $-P+P S$ & 0.01541 & 135 & PLIO + Methanol $\stackrel{X_{\mathrm{n}}}{\rightarrow}$ Methyl $-L I+P O$ & 0.00770 & 135 \\
\hline Methyl $-P+P S \stackrel{X_{14}}{\longrightarrow}$ Methanol + PPS & 0.001867 & 103 & Methyl $-L I+P O \stackrel{X_{0}}{\longrightarrow} P L I O+$ Methanol & 0.001867 & 103 \\
\hline$P S+$ Methanal $\stackrel{K_{33}}{\longrightarrow}$ Methyl $-P+1-S$ & 0.05330 & 17.4 & $\mathrm{LIO}+$ Metharal $\stackrel{K_{3}}{\longrightarrow}$ Methyl $-O+1-L I$ & 0.05330 & 17.4 \\
\hline Methyl $-P+1-S \stackrel{N_{x}}{\longrightarrow}$ Methanal $+P S$ & 0.002217 & 162 & Methyl $-O+1-L I I \stackrel{R_{94}}{\longrightarrow} \mathrm{LHO}+$ Methanal & 0002217 & 162 \\
\hline $1-S+$ Methanol $\stackrel{N_{D}}{\longrightarrow}$ Methyl $-S+$ Glycerol & 0.05754 & 6.2 & $L S O+$ Methanal $\stackrel{K_{\text {Is }}}{\longrightarrow}$ Methyl $-L f+1-O$ & 0.05330 & 17.4 \\
\hline Methyd $-S+$ Glyceral $\stackrel{N_{2}}{\longrightarrow}$ Methanal $+1-S$ & 0.000267 & 11.9 & Methyl $-L I+1-O \stackrel{X_{T 6}}{\longrightarrow}$ Methanol $+L O O$ & 0.002217 & 16.2 \\
\hline PS + Methanal $\stackrel{K_{30}}{\longrightarrow}$ Methyl $-S+1-P$ & 0.05330 & 17.4 & oOS + Metharol $\stackrel{K_{\pi}}{\rightarrow}$ Methyl $-S+00$ & 0.00770 & 13.5 \\
\hline Methyl $-S+1-P \stackrel{X_{x}}{\longrightarrow}$ Methanal $+P S$ & 0.002217 & 162 & Methyl $-S+0 O \stackrel{X_{*}}{\rightarrow}$ Met hanal $+00 S$ & 0.001867 & 103 \\
\hline$P P O+$ Methanol $\stackrel{X_{31}}{\longrightarrow}$ Methyl $-O+P P$ & 0.00770 & 135 & OOS + Methanol $\stackrel{X_{m}}{\longrightarrow}$ Met hyl $-O+$ aS & 0.01541 & 135 \\
\hline Methyl $-O+P P \stackrel{N_{33}}{\longrightarrow}$ Methanol + PPO & 0.001867 & 10.3 & OS + Methyl $-O \stackrel{K_{0}}{\longrightarrow} O O S+$ Methanal & 0.001867 & 103 \\
\hline Metharal $+P P O \stackrel{K_{y 3}}{\longrightarrow}$ Methyl $-P+P O$ & 001541 & 13.5 & OS + Methanal $\stackrel{K_{51}}{\longrightarrow}$ Methyl $-O+1-S$ & 005330 & 17.4 \\
\hline Methyl $-P+P O \stackrel{X_{34}}{\longrightarrow} P P O+$ Methanal & 0.001867 & 103 & Methyl $-O+1-S \stackrel{X_{e a}}{\longrightarrow} O S+$ Methanol & 0.002217 & 162 \\
\hline$P O+$ Methanal $\stackrel{N_{35}}{\longrightarrow}$ Methyl $-P+1-O$ & 0.05330 & 17.4 & oS + Methanal $\stackrel{N_{63}}{\longrightarrow}$ Methyl $-S+1-O$ & 0.05330 & 17.4 \\
\hline Methyl $-P+1-O \stackrel{K_{\text {m }}}{\longrightarrow} P O+$ Metharal & 0.002217 & 16.2 & Methyl $-S+1-O \stackrel{K_{E 4}}{\longrightarrow}$ Methanal + as & 0.002217 & 16.2 \\
\hline$P O+$ Methanal $\stackrel{N_{39}}{\longrightarrow}$ Methyl $-O+1-P$ & 005330 & 17.4 & OOLI + Methanol $\stackrel{X_{0}}{\longrightarrow}$ Methyl $-L I+O O$ & 0.00770 & 135 \\
\hline Methyl $-O+1-P \stackrel{X_{N}}{\longrightarrow}$ Met hanal $+P O$ & 0.002217 & 16.2 & Methyl $-L I+O O \stackrel{X_{\alpha}}{\longrightarrow} O O L I+$ Methanol & 0.001867 & 103 \\
\hline MMP + Methanol $\stackrel{X_{w n}}{\longrightarrow}$ Methyl $-P+M M$ & 0.00770 & 13.5 & OOLI + Metharol $\stackrel{N_{g}}{\longrightarrow}$ Methyl $-O+L I O$ & 0.01541 & 13.5 \\
\hline Methyl $-P+M M \stackrel{R_{40}}{\longrightarrow}$ Methanol + MMP & 0.001867 & 103 & Methyl $-0+$ LIO $\stackrel{K_{0}}{\longrightarrow}$ Methanal + OOLf & 0001867 & 103 \\
\hline MMP + Methanol $\stackrel{M_{41}}{\longrightarrow}$ Methyl $-M+M P$ & 0.01541 & 135 & MPLI + Methanol $\stackrel{K_{0}}{\longrightarrow}$ Methyl $-L I+M P$ & 0.00770 & 135 \\
\hline Methyl $-\mathbf{M}+\mathbf{M P} \stackrel{N_{42}}{\longrightarrow}$ Methanol + MMP & 0.001867 & 103 & Methyl $-L I+M P \stackrel{X_{\infty}}{\longrightarrow} M P L I+$ Methanol & 0.001867 & 103 \\
\hline$M P+$ Methanal $\stackrel{X_{43}}{\longrightarrow}$ Methyl $-P+1-M$ & 0.05330 & 17.4 & MPLI + Metharol $\stackrel{K_{\text {m }}}{\longrightarrow}$ Methyl $-M+P L I$ & 0.00770 & 13.5 \\
\hline Methyl $-P+1-M \stackrel{X_{4+}}{\longrightarrow}$ Methanal $+M P$ & 0.002217 & 162 & Methyl $-M+P L I \stackrel{X_{e}}{\longrightarrow} M P L I+$ Methanol & 0001867 & 103 \\
\hline$M P+$ Methanal $\stackrel{N_{45}}{\longrightarrow}$ Methyl $-M+1-P$ & 0.05330 & 17.4 & MPLI + Methanol $\stackrel{N_{s}}{\longrightarrow}$ Methyl $-P+M L I$ & 0.00770 & 135 \\
\hline Methyl $-M+1-P \stackrel{X_{t}}{\rightarrow}$ Methanal $+M P$ & 0.002217 & 162 & Methyl $-P+M L I \stackrel{N_{9}}{\rightarrow} M P L I+$ Methanol & 0.001867 & 103 \\
\hline$P P L I+$ Methanol $\stackrel{R_{4}}{\longrightarrow}$ Methyl $-L I+P P$ & 0.00730 & 135 & $M L I+$ Methanal $\stackrel{K_{56}}{\longrightarrow}$ Methyl $-M+1-L I$ & 0.05330 & 17.4 \\
\hline Methyl $-L I+P P \stackrel{K_{4}}{\longrightarrow}$ Methanol $+P P L I$ & 0.001867 & 103 & Methyl $-M+1-L I \stackrel{N_{\text {G }}}{\longrightarrow}$ Methanal $+M L I$ & 0.002217 & 16.2 \\
\hline$P P L I+$ Methanol $\stackrel{K_{49}}{\longrightarrow}$ Methyl $-P+P L I$ & 0.01541 & 135 & $M L I+$ Methanal $\stackrel{X_{\varphi T}}{\longrightarrow}$ Methyl $-L I+1-M$ & 0.05330 & 17.4 \\
\hline Met hyl $-P+P L I \stackrel{X_{s 0}}{\longrightarrow} P P L I+$ Met hanal & 0.001867 & 10.3 & Methyl $-L I+1-M \stackrel{K_{95}}{\longrightarrow} M L I+$ Metharol & 0.002217 & 162 \\
\hline
\end{tabular}

The washing column (C-04) is modeled with the UNIF-DMD property method (Dortmund modified UNIFAC), as the UNIQ-RK methods can't handle the water washing/separation accurately in the presence of $\mathrm{H}_{2} \mathrm{SO}_{4}$ traces from the previous pre-treatment unit. 


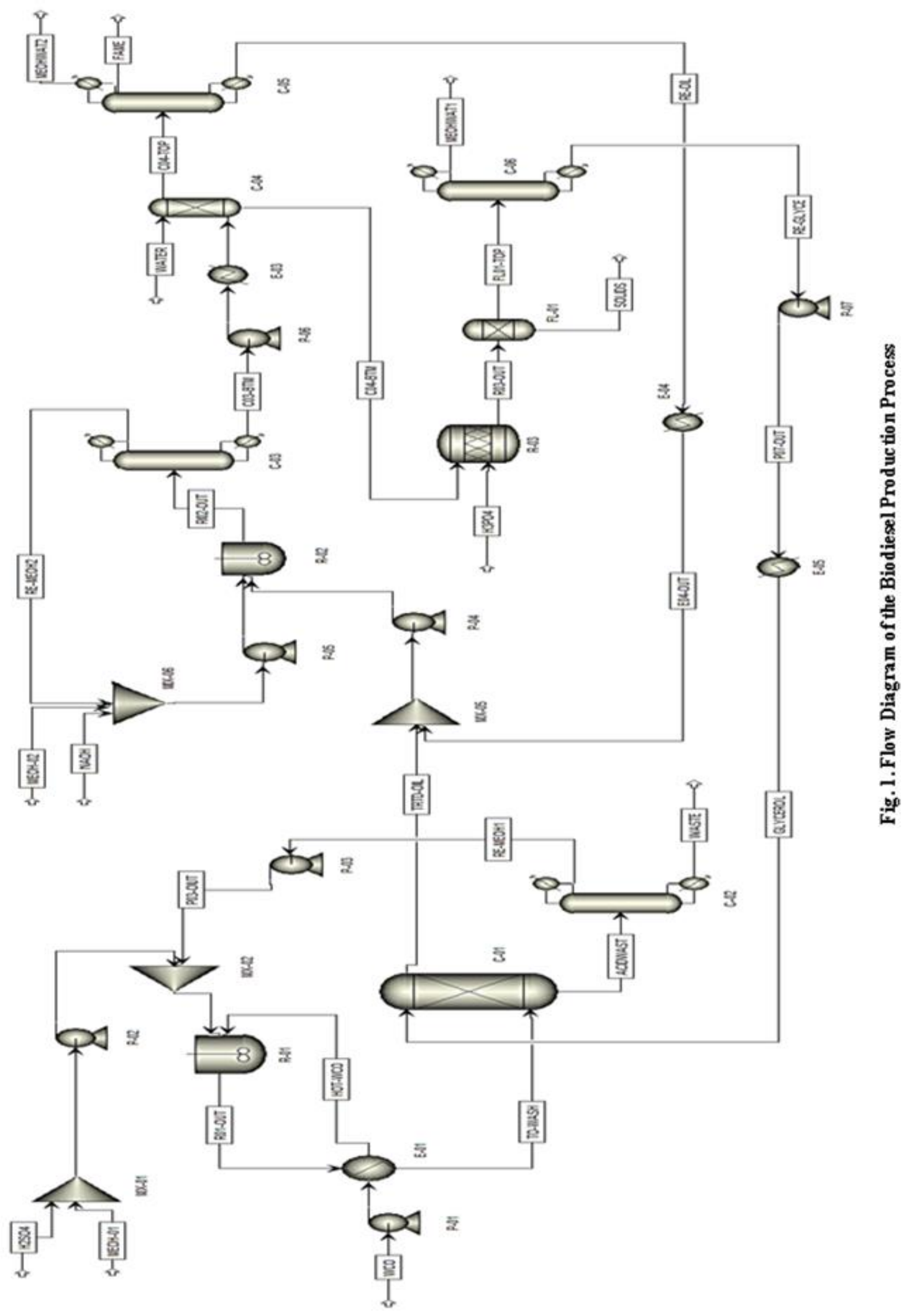




\section{PROCESS DESIGN AND SIMULATION}

The process consists of two steps, first step is the pre-treatment where the WCO feed esterification with methanol in presence of acid catalyst $\left(\mathrm{H}_{2} \mathrm{SO}_{4}\right)$ occurs. The WCO was heated to $60{ }^{\circ} \mathrm{C}$ in heat exchanger (E-01) before entering esterification reactor $\mathrm{R}-01$. The fresh methanol stream is combined with the $\mathrm{H}_{2} \mathrm{SO}_{4}$ stream and mixed then with the recycled methanol stream (RE-MEOH1). The resulting mixture from $\mathrm{MX}-02$ is pumped into the reactor $\mathrm{R}-01$. In R-01, the reaction was carried out at $60^{\circ} \mathrm{C}, 4 \mathrm{bar}$, a $6: 1$ molar ratio of methanol to FFA and $1 \%$ sulfuric acid (based on oil). All the free fatty acids in the reactor were converted to methyl esters in $120 \mathrm{~min}$ [27].

The resulting water and acid catalyst $\left(\mathrm{H}_{2} \mathrm{SO}_{4}\right)$ from $\mathrm{R}-01$ need to be completely removed before proceeding to the alkali-catalyzed transesterification by using glycerin as a liquid entraining agent. Recycled pure glycerin (100\%) from glycerin purification column C-06 at $45^{\circ} \mathrm{C}$ and 4 bar is used in washing the reactor effluent (R01-OUT) in C-01 column. The resulting washed stream TRTD-OIL is consisted only of refined oil and the resulting methyl esters. This stream was sent to downstream transesterification unit. The bottom stream from C-01 composes of unreacted methanol, glycerol, sulfuric acid, water and traces of esters. The methanol in this stream was recovered in C-02. Recovered methanol stream RE-MEOH1 was obtained from the top of $\mathrm{C}-02$ at $28^{\circ} \mathrm{C}$ and 0.2 bar, with $99 \%$ recovery of the total methanol fed to the column, and purity $>99 \%$ of methanol. Vacuum distillation was used to keep the temperature under $150^{\circ} \mathrm{C}$ as FAME and glycerol are susceptible to thermal decomposition above $250^{\circ} \mathrm{C}$ and $150^{\circ} \mathrm{C}$ respectively [28, 29].

The bottom stream of C-02 (WASTE) composed of glycerol, methanol, sulfuric acid and water, but due to the presence of sulfuric acid, this stream was not reused and is treated as waste.

Step two in the biodiesel production process is the alkali-catalyzed transesterification. The TRTD-OIL stream from pre-treatment step 1 is mixed with the recycle oil stream (RE-OIL) which is heated in the heater E-04. The outlet stream from MIX-05 is pumped into the reactor R-02. The fresh methanol stream (MEOH-02) is combined with the recycled methanol stream (REMOH-02) and the anhydrous sodium hydroxide $\mathrm{NAOH}$ in the mixer MX-06. The resulted stream from MX-06 is pumped into R-02. The reaction was carried out at a 6:1 molar ratio of methanol to oil, $1 \%$ sodium hydroxide (based on oil), $60^{\circ} \mathrm{C}$ and 4 bar. Anhydrous $\mathrm{NaOH}$ is used as recommended for commercially viable alkali-catalyzed systems $[10,18]$. In R-02, all reactions were performed according to the kinetics of the reactions shown in Table 4 with a residence time of 60 minutes. The reactions convert $99 \%$ of the oil to FAME.

The methanol in stream R02-OUT emerged from R-02 was recovered in C-03 tower. The top stream of C-03 with purity of $>99.9 \%$ of methanol is mixed with fresh methanol to R-02. Vacuum distillation was used to keep the temperature under $150^{\circ} \mathrm{C}$ as FAME and glycerol are susceptible to thermal decomposition above $250^{\circ} \mathrm{C}$ and $150^{\circ} \mathrm{C}$, respectively [28, 29]. The bottom stream of C-03 containing all the FAME from the reactor was pumped by $\mathrm{P}-06$, heated by E-03 then washed in the water washing column C-04 where FAME was completely separated from the glycerol. The content of other compounds, such as vegetable oil, methanol and water in the FAME were all less than $1 \%$. The top product stream from
C-04 (C-04-TOP) composed of FAME, water and methanol was forwarded to C-05 to purify the FAME product where water and methanol were removed. A FAME product with 99.3\% purity was obtained as a final biodiesel product.

The bottom stream from C-04 (C04-BTM) is proceeded to neutralization reactor R-03 to remove sodium hydroxide by adding pure phosphoric acid $\left(\mathrm{H}_{3} \mathrm{PO}_{4}\right)$ with $100 \%$ purity. It is assumed that the conversion in R-03 is $100 \%$. The resulting $\mathrm{Na}_{3} \mathrm{PO}_{4}$ was removed in gravity separator (filter) FL-01. The remaining stream composed mainly of glycerin with little of water, methanol and traces of oil is entered a distillation column C-06 for glycerin purification, where pure glycerin obtained from the bottom and recycled back to the washing tower C-01. The remaining water, methanol and other traces are obtained from the top of column. Table 4 illustrates the simulation results of the biodiesel production process.

\section{RESULT AND DISCUSSION}

\section{A. Effect of Reaction Temperature}

Keeping all reaction conditions constant and changing only the reaction temperature, the simulation results showed that at the same reaction time, increasing reaction temperature increased reaction conversion (Fig. 2). From Arrhenius, high temperature would push the process to move forward and resulted in more conversion and more products. However, from Fig. 2 and especially with higher residence time, the effect of increasing temperature above $65^{\circ} \mathrm{C}$ on conversion is less than $0.2 \%$ and would be energy wasting. That's makes temperature an important varying variable for optimization.

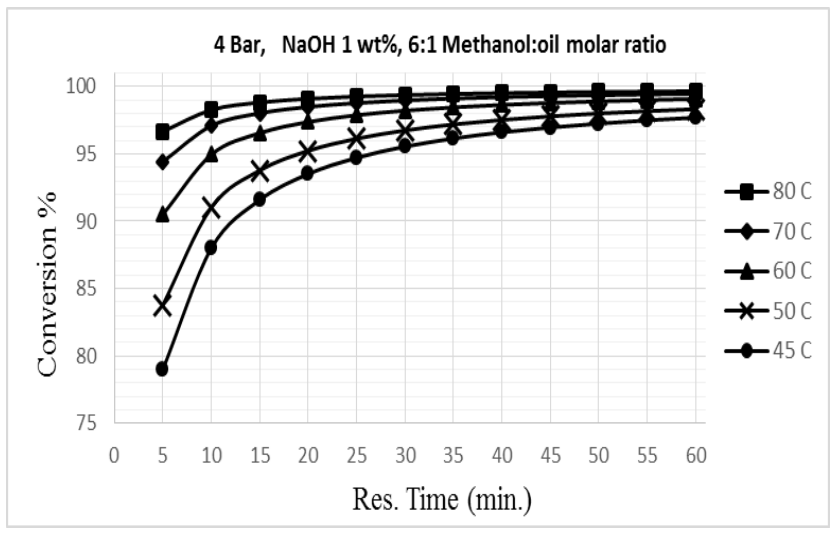

Fig. 1. Effect of reaction temperature on conversion \% Table IV with a residence time of 60 minutes. The reactions convert $99 \%$ of the oil to FAME. 
Table IV Simulation results of biodiesel production process.

\begin{tabular}{|c|c|c|c|c|c|c|c|c|}
\hline & Units & WCO & MEOH-01 & H2SO4 & P02-OUT & P03-OUT & MX02-OUT & HOT-WCO \\
\hline From & & & & & $\mathrm{P}-02$ & $\mathrm{P}-03$ & MX-02 & E-01 \\
\hline To & & P-01 & MX-01 & MX-01 & MX-02 & MX-02 & R-01 & R-01 \\
\hline Phase & & Liquid & Liquid & Liquid & Liquid & Liquid & Liquid & Liquid \\
\hline Temperature & ${ }^{\circ} \mathrm{C}$ & 25 & 25 & 25 & 25.11 & 28.55 & 28.36 & 50 \\
\hline Pressure & bar & 1 & 1 & 1 & 4 & 4 & 4 & 4 \\
\hline Mass Flows & $\mathrm{kg} / \mathrm{hr}$ & 1100 & 24.24 & 3.3 & 27.54 & 426.56 & 454.1 & 1100 \\
\hline Mole Flows & $\mathrm{kmol} / \mathrm{hr}$ & 1.49 & 0.76 & 0.03 & 0.79 & 13.35 & 14.14 & 1.49 \\
\hline & Units & R01-OUT & TO-WASH & ACIDWAST & WASTE & RE-MEOH1 & MEOH-02 & NAOH \\
\hline From & & R-01 & E-01 & C-01 & C-02 & C-02 & & \\
\hline To & & E-01 & C-01 & C-02 & & $\mathrm{P}-03$ & MX-06 & MX-06 \\
\hline Phase & & Liquid & Liquid & Liquid & Liquid & Liquid & Liquid & Liquid \\
\hline Temperature & ${ }^{\circ} \mathrm{C}$ & 60 & 45.5 & 45.84 & 87.98 & 28.41 & 25 & 25 \\
\hline Pressure & bar & 4 & 4 & 2 & 0.3 & 0.2 & 1 & 1 \\
\hline Mass Flows & kg/hr & 1554.1 & 1554.1 & 563.64 & 137.09 & 426.56 & 114.03 & 11.03 \\
\hline Mole Flows & kmol/hr & 15.63 & 15.63 & 14.99 & 1.64 & 13.35 & 3.56 & 0.28 \\
\hline & Units & RE-MEOH2 & P05-OUT & R02-OUT & C03-BTM & E03-OUT & WATER & C04-BTM \\
\hline From & & C-03 & P-05 & R-02 & C-03 & E-03 & & C-04 \\
\hline To & & MX-06 & $\mathrm{R}-02$ & C-03 & P-06 & C-04 & C-04 & $\mathrm{R}-03$ \\
\hline Phase & & Liquid & Liquid & Liquid & Liquid & Liquid & Liquid & Liquid \\
\hline Temperature & ${ }^{\circ} \mathrm{C}$ & 28.32 & 27.39 & 60 & 93.76 & 60 & 25 & 60.6 \\
\hline Pressure & bar & 0.2 & 4 & 4 & 0.3 & 1.5 & 1.1 & 1.2 \\
\hline Mass Flows & $\mathrm{kg} / \mathrm{hr}$ & 250.52 & 375.58 & 1505.81 & 1255.3 & 1255.3 & 50 & 183.2 \\
\hline Mole Flows & $\mathrm{kmol} / \mathrm{hr}$ & 7.82 & 11.65 & 13.61 & 5.79 & 5.79 & 2.78 & 4.41 \\
\hline & Units & H3PO4 & R03-OUT & SOLIDS & FL01-TOP & MEOHWAT1 & RE-GLYCE & C04-TOP \\
\hline From & & & R-03 & FL-01 & FL-01 & C-06 & C-06 & C-04 \\
\hline To & & $\mathrm{R}-03$ & FL-01 & & C-06 & & $\mathrm{P}-07$ & C-05 \\
\hline Phase & & Liquid & Liquid & Liquid & Liquid & Liquid & Liquid & Liquid \\
\hline Temperature & ${ }^{\circ} \mathrm{C}$ & 20 & 50 & 50 & 50 & 67.96 & 261.99 & 57.68 \\
\hline Pressure & bar & 1.1 & 1.1 & 1.1 & 1.1 & 0.4 & 0.5 & 1.1 \\
\hline Mass Flows & kg/hr & 45.04 & 228.24 & 15.07 & 213.17 & 97.89 & 115.28 & 1122.1 \\
\hline Mole Flows & $\mathbf{k m o l} / \mathbf{h r}$ & 2.09 & 6.5 & 0.09 & 6.41 & 5.16 & 1.25 & 4.16 \\
\hline & Units & RE-OIL & MEOHWAT2 & FAME & & & & \\
\hline From & & C-05 & C- 05 & C-05 & & & & \\
\hline To & & E-04 & & & & & & \\
\hline Phase & & Liquid & Vapor & Liquid & & & & \\
\hline Temperature & ${ }^{\circ} \mathrm{C}$ & 291.82 & 140 & 140 & & & & \\
\hline Pressure & bar & 0.2 & 0.1 & 0.1 & & & & \\
\hline Mass Flows & kg/hr & 24.5 & 4.59 & 1093.01 & & & & \\
\hline Mole Flows & $\mathbf{k m o l} / \mathbf{h r}$ & 0.06 & 0.22 & 3.88 & & & & \\
\hline
\end{tabular}

\section{B. Effect of reaction Pressure}

By changing the reaction pressure while all other variables are constant, as the reaction occurs only in the liquid phase, the simulation showed that at high temperature $\left(75^{\circ} \mathrm{C}\right)$ lowering the pressure would allow some reactant to be in the vapor phase which reduces the reaction conversion (Fig. 3). A pressure of 4 bar found to be reasonable to keep the reaction in liquid phase for most temperature ranges (Figs. 3 and 4) in the study, and hence the pressure wouldn't be used in the optimization step.

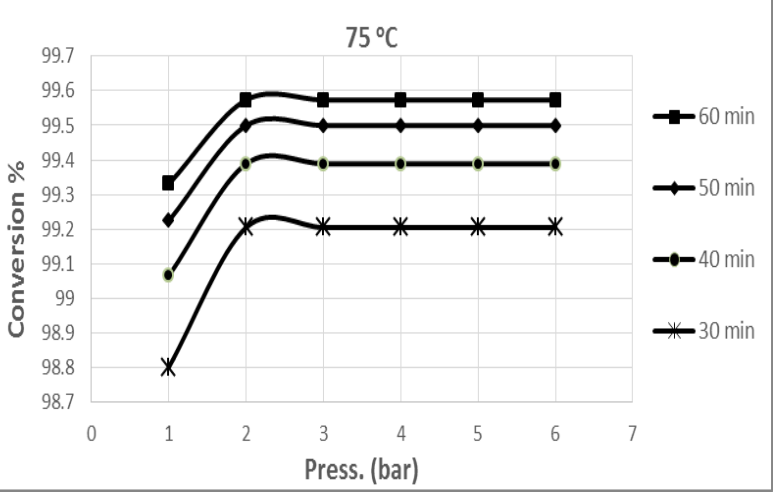

Fig. 3. Effect of Pressure on conversion $\%$ at $75^{\circ} \mathrm{C}$

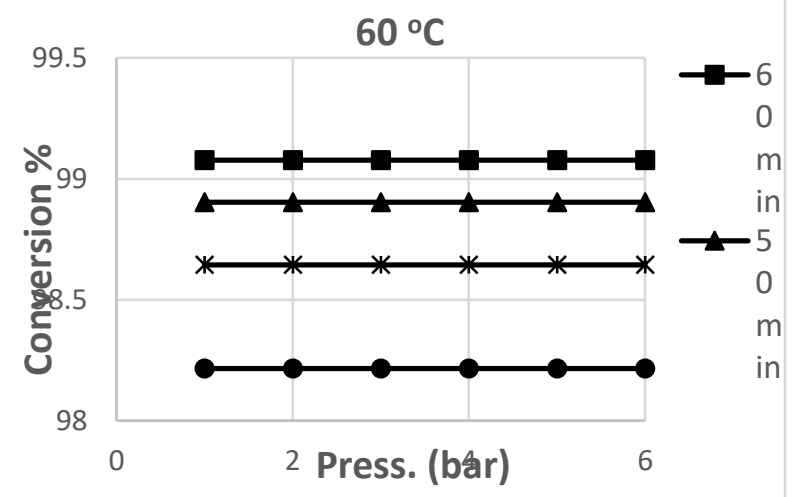

Fig. 4. Effect of Pressure on conversion $\%$ at $60^{\circ} \mathrm{C}$

C. Effect of reaction time

Also, from Fig. 2 we can see that increasing the reaction time at the same temperature increases the reaction conversion. The curves show clearly that the change of conversion with time is very high in the first $20-40 \mathrm{~min}$. where most curves reach the 95\% conversion, then any increase in time leads to a slight increase in conversion. Hence the reaction time also will be used as a varying variable in the optimization. 


\section{Effect of alkali catalyst ( $\mathrm{Na} \mathrm{OH})$ concentration}

Fig. 5 shows that increasing the catalyst concentration increases the reaction conversion till it reaches $99 \%$ conversion at $1 \mathrm{wt} . \%$. of $\mathrm{NaOH}$, then the effect of increasing the catalyst didn't show a significant effect. Thus, increasing the concentration above $1 \%$ wt. would be meaningless especially at high temperatures.

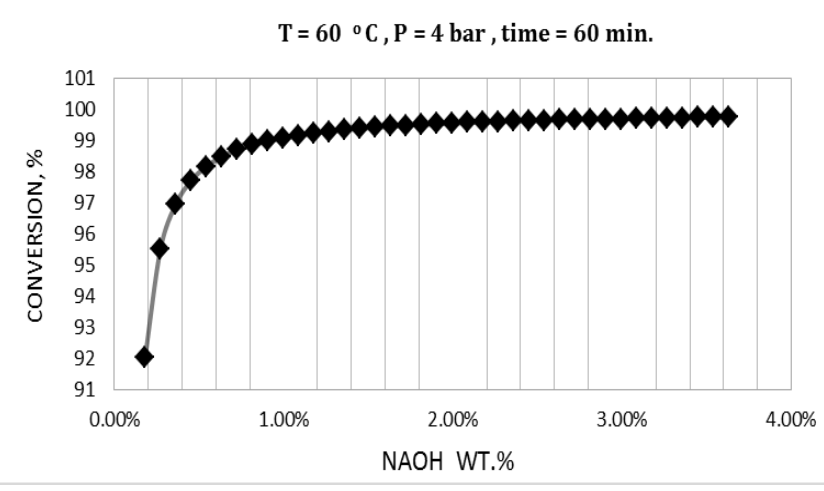

Fig. 5. Effect of catalyst concentration on conversion \%

\section{E. Effect of methanol: oil ratio}

From Fig. 6, increasing the methanol: oil molar ratio increases the reaction conversion. Also, it is noted that any ratio higher than $6: 1$ has a little effect on conversion \%. That because, increasing ratio would increase the amount of methanol and it would be difficult to recover all unreacted methanol and more energy would be consumed. Moreover, some methanol might be lost from its vaporization.

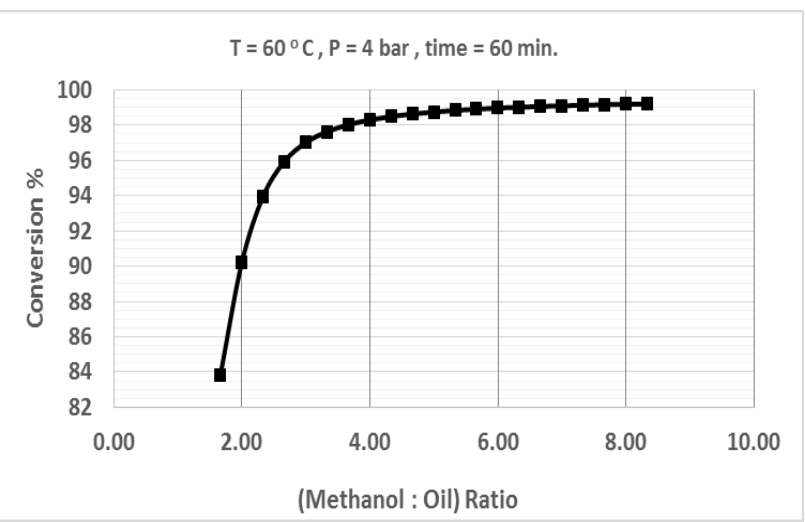

Fig. 6. Effect of methanol: oil ratio

\section{PROCESS OPTIMIZATION}

Considering the effect of various parameters studied, an optimization model was created for the process to find the optimum values for these parameters. The objective function for optimization is chosen as the maximization of the profit as presented in Equations (6) to (10).

$$
\begin{array}{r}
\text { Profit }=\text { production Revenue } \\
- \text { operating cost }
\end{array}
$$

production Revenue $=\mathrm{FAME}_{\text {Prod }} \cdot F A M E_{\text {Price }}$ operating cost $=$ Raw material cost

$$
+ \text { Uitilities cost }
$$

$$
\begin{aligned}
& \text { Raw material cost }=M_{W C O} \cdot P_{W C O}+M_{\text {Meth }} \cdot P_{\text {meth }}+ \\
& M_{\mathrm{H}_{2} \mathrm{SO}_{4}} \cdot P_{\mathrm{H}_{2} \mathrm{SO}_{4}}+M_{\mathrm{NaOH}} \cdot P_{\mathrm{NaOH}}+ \\
& M_{\mathrm{H}_{3} \mathrm{PO}_{4}} \cdot P_{\mathrm{H}_{3} \mathrm{PO}_{4}} \\
& \text { Uitilities cost }=Q_{\text {elect }} \cdot C_{\text {elect }}+Q_{\text {heating }} \cdot C_{\text {heating }}+ \\
& Q_{\text {cooling }} \cdot C_{\text {cooling }}
\end{aligned}
$$

Where FAME $E_{\text {Prod }}$ and FAME $E_{\text {Price }}$ are the production and the price of the biodiesel produced, respectively; $\mathrm{M}_{\mathrm{WCO}}, \mathrm{M}_{\mathrm{Meth}}$, $\mathrm{M}_{\mathrm{H}_{2} \mathrm{SO}_{4}}, \mathrm{M}_{\mathrm{NaOH}}, \mathrm{M}_{\mathrm{H}_{3} \mathrm{PO}_{4}}$ are mass flowrate of waste cooking oil, methanol, sulfuric acid, sodium hydroxide and phosphoric acid, respectively; $\mathrm{P}_{\mathrm{WCO}}, \mathrm{P}_{\text {meth }}, \mathrm{P}_{\mathrm{H}_{2} \mathrm{SO}_{4}}, \mathrm{P}_{\mathrm{NaOH}}, \mathrm{P}_{\mathrm{H}_{3} \mathrm{PO}_{4}}$ are the unit cost of waste cooking oil, methanol, sulfuric acid, sodium hydroxide and phosphoric acid, respectively; $\mathrm{Q}_{\text {elect }}, \mathrm{Q}_{\text {heating }}, \mathrm{Q}_{\text {cooling }}$ are the energy consumption by using electricity, steam and cooling water, respectively; $\mathrm{C}_{\text {elect }}$, $\mathrm{C}_{\text {heating }}, \mathrm{C}_{\text {cooling }}$ are the unit energy cost of electricity, heating and cooling duties, respectively.

The profit is maximized by varying reaction temperature, reaction time, methanol to oil ratio and the $\mathrm{NaOH}$ concentration.

Several constraints are used in the optimization to make the biodiesel production process operate stably and safely. These process constraints are described as follows:

1) The temperature < $103.5 \mathrm{C}$ (the boiling point of methanol @ operating pressure of 4 bar)

2) FAME content of biodiesel $>96.5 \%$ (matching the European Standard for biodiesel EN-14214)

Aspen Plus optimization tool was used and the objective function formula is written in FORTRAN code. The results of the optimization compared to the design values are listed in Table V.

Table V Optimization results for varying variables.

\begin{tabular}{|c|c|c|}
\hline Variable & Initial value & Optimum value \\
\hline Reaction & 60 & 45 \\
\hline Reaction Time (min) & 60 & 49 \\
\hline NaOH concentration & 1 & 0.25 \\
\hline Methanol : Oil molar & $6: 1$ & $7.2: 1$ \\
\hline
\end{tabular}

Also, the amount of waste streams was reduced as shown in Table VI. The importance of reducing this waste is a low waste disposal fee. Plus, it's environmentally friendly.

Table VI: Optimization results for waste streams.

\begin{tabular}{|c|c|c|}
\hline Waste stream & $\begin{array}{c}\text { First value } \\
(\mathrm{kg} / \mathrm{hr})\end{array}$ & $\begin{array}{c}\text { Optimization result } \\
(\mathrm{kg} / \mathrm{hr})\end{array}$ \\
\hline Methanol-water from & 5 & 6 \\
\hline Methanol-water from & 98 & 67 \\
\hline Solid waste from R-03 & 15 & 4 \\
\hline
\end{tabular}

The optimum values obtained resulted in about 3\% increase in the profit and gave almost the same conversion percent (>99\%). In addition, the specifications of the produced biodiesel as measured by physical properties were all combatable with either ASTM or EN standards as illustrated in Table VII. 
Table VII: Major Physical Properties of Biodiesel product

\begin{tabular}{|c|c|c|c|}
\hline Specification & $\begin{array}{c}\text { FAME } \\
\text { product }\end{array}$ & $\begin{array}{c}\text { ASTM } \\
\text { D6751 }\end{array}$ & EN 14214 \\
\hline $\begin{array}{c}\text { Ester content, } \\
\text { wt\% }\end{array}$ & $98 \%$ & - & Min. 96.5\% \\
\hline $\begin{array}{c}\text { Density at } \\
15^{\circ} \mathrm{C}, \mathrm{kg} / \mathrm{m} 3\end{array}$ & 878.8 & - & $860-900$ \\
\hline Flash Point, ${ }^{\circ} \mathrm{C}$ & 155 & Min. 130 & Min. 120 \\
\hline Cetane No. & 62 & Min. 47 & Min. 51 \\
\hline $\begin{array}{c}\text { Kinematic } \\
\text { viscosity, } 40^{\circ} \mathrm{C}\end{array}$ & $\begin{array}{c}4.76 \\
\mathrm{~mm} 2 / \mathrm{s}\end{array}$ & $\begin{array}{c}1.9-6.0 \\
\mathrm{~mm} 2 / \mathrm{s}\end{array}$ & $\begin{array}{c}3.5-5 \\
\mathrm{~mm} 2 / \mathrm{s}\end{array}$ \\
\hline
\end{tabular}

\section{ECONOMIC STUDY}

The process performance of the optimized case and the base case are illustrated in Table VIII. The presented biodiesel production process from waste cooking oil can produce biodiesel with properties similar to diesel fuel produced from crude oil. The process has the advantages of low energy consumption and good economic benefit.

An economic study is presented in this work for the process to demonstrate the initial investment and the payback period (Table VIII). The operation time is assumed 330 days/year.

As presented in Table VIII the optimized model can achieve about $3 \%$ increase in the profit with 1 year payback period.

Table VIII: Process performance and economic study of the optimized and the base case.

\begin{tabular}{|c|c|c|c|c|}
\hline Items & Price & Price source & $\begin{array}{c}\text { Base case } \\
(\$ / y r)\end{array}$ & $\begin{array}{c}\text { Optimize } \\
\text { d case } \\
(\$ / y r)\end{array}$ \\
\hline $\begin{array}{l}\text { Biodiesel } \\
\text { productio } \\
\text { n revenue }\end{array}$ & $\begin{array}{l}1072 \\
\$ / \text { ton }\end{array}$ & $\begin{array}{c}\text { afdc.energy.go } \\
\text { v } \\
\text { Neste.com } \\
2019\end{array}$ & $\begin{array}{c}9842246 . \\
4\end{array}$ & $\begin{array}{c}9858338 . \\
2\end{array}$ \\
\hline $\begin{array}{c}\text { Waste } \\
\text { cooking } \\
\text { oil cost } \\
\end{array}$ & $\begin{array}{l}525 \\
\$ / \text { ton }\end{array}$ & $\begin{array}{c}\text { Average price } \\
\text { (2019) }\end{array}$ & 4851000 & 4851000 \\
\hline $\begin{array}{c}\text { Methanol } \\
\text { cost }\end{array}$ & $\begin{array}{l}432 \\
\text { \$/ton } \\
\end{array}$ & $\begin{array}{l}\text { Methanex.com } \\
\text { (2019) } \\
\end{array}$ & 500774.4 & $\begin{array}{c}490716.0 \\
2 \\
\end{array}$ \\
\hline $\begin{array}{c}\mathrm{H}_{2} \mathrm{SO}_{4} \\
\text { cost } \\
\end{array}$ & 53 \$/ton & $\begin{array}{c}\text { Echemi.com } \\
(2019) \\
\end{array}$ & 1335.6 & 1469.16 \\
\hline $\begin{array}{c}\mathrm{NaOH} \\
\text { cost }\end{array}$ & $\begin{array}{l}650 \\
\$ / \text { ton } \\
\end{array}$ & $\begin{array}{c}\text { Echemi.com } \\
(2019)\end{array}$ & 60060 & $\begin{array}{c}17834.41 \\
8 \\
\end{array}$ \\
\hline $\begin{array}{c}\mathrm{H}_{3} \mathrm{PO}_{4} \\
\text { cost }\end{array}$ & $\begin{array}{c}162 \\
\$ / \text { ton }\end{array}$ & $\begin{array}{c}\text { Echemi.com } \\
(2019)\end{array}$ & 61236 & $\begin{array}{c}18152.18 \\
4 \\
\end{array}$ \\
\hline $\begin{array}{l}\text { Electricit } \\
\text { y cost }\end{array}$ & $\begin{array}{c}0.0775 \\
\text { \$/KW.hr }\end{array}$ & $\begin{array}{c}\text { Egyptian local } \\
\text { market at } \\
2019 \\
\end{array}$ & 304.92 & 324.676 \\
\hline $\begin{array}{l}\text { Medium } \\
\text { Press. } \\
\text { Steam } \\
\text { cost } \\
\end{array}$ & $\begin{array}{c}4.47645 \\
8 \text { \$/ton }\end{array}$ & $\begin{array}{c}\text { Egyptian local } \\
\text { market at } \\
2019\end{array}$ & 75742.8 & 73739.5 \\
\hline $\begin{array}{l}\text { Heating } \\
\text { Duty cost }\end{array}$ & $\begin{array}{l}4.25 \\
\$ / G J \\
\end{array}$ & $\begin{array}{c}\text { Egyptian local } \\
\text { market at } \\
2019 \\
\end{array}$ & 76356 & 75888.33 \\
\hline
\end{tabular}

The present work presents a proposed rigorous model using detailed kinetics reaction for the alkali transesterification of waste cooking oil with methanol and alkali catalyst $(\mathrm{NaOH})$. The simulation software used was the Aspen Plus software version 11 with UNIQUAC activity model with Redlich-Kwong Equation of State with Henry's law. Then the effect of different parameters on the process like temperature, pressure, residence time, methanol to oil ratio and catalyst $(\mathrm{NaOH})$ percentage were studied.

Finally, optimization of the process is carried out to find the best conditions for maximum profit and maximum production.

The results showed that, the reaction temperature of $45^{\circ} \mathrm{C}$, reaction time of $49 \mathrm{~min}, \mathrm{NaOH}$ concentration of $0.25 \mathrm{wt} \%$, and methanol: oil molar ratio of 7.2:1 were achieved . The optimum values result in about $3 \%$ increase in the profit and gave almost the same conversion percent (>99\%). Also, the same biodiesel product quantity and quality/specification which was compatible with both ASTM D6751 and EN 14214 is obtained.

\section{REFERENCES}

1. A. Nag, "Biofuels Refining and Performance," McGraw Hill Professional, 2008.

2. ASTM, D 6751 Standard Specification for Biodiesel Fuel Blend Stock (B100) for Middle Distillate Fuels. ASTM International.

3. W. Körbitz, "Biodiesel production in Europe and North America: an encouraging prospect," Renewable Energy, 1999, vol. 16, pp. 1078-1083.

4. O. A. Kuti, J. Zhu, K. Nishida, X. Wang, Z. Huang, "Characterization of spray and combustion processes of biodiesel fuel injected by diesel engine common rail system," Fuel, 2013, vol. 104, pp. 838-846.

5. Ö. Can, "Combustion characteristics, performance and exhaust emissions of a diesel engine fueled with a waste cooking oil biodiese mixture," Energy Conversion and Management, 2014, vol. 87, pp. 676-686.

6. T. Krawczyk, "Biodiesel-alternative fuel makes inroads but hurdles remain," inform, 1996, vol. 7, pp. 801-829. 
7. A. Demirbaş, "Biodiesel from vegetable oils via transesterification in supercritical methanol," Energy conversion and management, 2002, vol. 43 (17), pp. 2349-2356.

8. S. Saka, D. Kusdiana, "Biodiesel fuel from rapeseed oil as prepared in supercritical methanol," Fuel, 2001, vol. 80 (2), pp. 225-231.

9. G. Santori, G. Di Nicola, M. Moglie, F. Polonara, "A review analyzing the industrial biodiesel production practice starting from vegetable oil refining," Applied energy, 2012, vol. 92, pp. 109-132.

10. B. Freedman, E. Pryde, T. Mounts, "Variables affecting the yields of fatty esters from transesterified vegetable oils," Journal of the American Oil Chemists' Society, 1984, vol. 61(10), pp. 1638-1643.

11. J. Connemann, J. Fischer, "Biodiesel in Europe 2000: Biodiesel Processing Technologies and Future Market Development. 1999 [cited 1999; 1-11].

12. M. Canakci, J. Van Gerpen, "Biodiesel production from oils and fats with high free fatty acids," Transactions of the ASAE, 2001, vol. 44(6), pp. 1429-1436.

13. G. Wiltsee, " Waste grease resource in 30 US metropolitan areas," in The Proceedings of Bioenergy 98 Conference, Wisconsin. 1998.

14. H. Noureddini, D. Zhu, "Kinetics of transesterification of soybean oil," Journal of the American Oil Chemists' Society, 1997, vol. 74(11), pp. 1457-1463.

15. D. Darnoko, M. Cheryan, "Kinetics of palm oil transesterification in a batch reactor," Journal of the American Oil Chemists' Society, 2000, vol. 77(12), pp. 1263-1267.

16. K.-S. Liu, "Preparation of fatty acid methyl esters for gas-chromatographic analysis of lipids in biological materials," Journal of the American Oil Chemists' Society, 1994, vol. 71(11), pp. 1179-1187.

17. Basu, H.N., Norris, M.E., Process for production of esters for use as a diesel fuel substitute using a non-alkaline catalyst. 1996, US Patent 5525126.

18. L. Jeromin, E. Peukert, G. Wollmann, "Process for the pre-esterification of free fatty acids in fats and oils," 1987, US Patent 4698186.

19. H. Lepper, L. Friesenhagen, "Process for the production of fatty acid esters of short-chain aliphatic alcohols from fats and/or oils containing free fatty acids," 1986, US Patent No 4,608,202.

20. Y. Watanabe, Y. Shimada, A. Sugihara, Y. Tominaga, "Enzymatic conversion of waste edible oil to biodiesel fuel in a fixed-bed bioreactor," Journal of the American Oil Chemists' Society, 2001, vol. 78(7), pp. 703-707.

21. Y. Zhang, M. A. Dube, D.D. McLean, M. Kates, "Biodiesel production from waste cooking oil: 1. Process design and technological assessment," Bioresource technology, 2003, vol. 89(1), pp. 1-16.

22. A.H. West, D. Posarac, N. Ellis, "Assessment of four biodiesel production processes using HYSYS.Plant," Bioresource technology, 2008, vol. 99(14), pp. 6587-6601.

23. J. Marchetti, V. Miguel, A. Errazu, "Techno-economic study of different alternatives for biodiesel production," Fuel Processing Technology, 2008, vol. 89(8), pp. 740-748.

24. P. C. Narváez, S. Rincón, F. Sánchez, "Kinetics of palm oil methanolysis," Journal of the American Oil Chemists' Society, 2007, 84(10), pp. 971-977.

25. Aspentech, Aspen Plus Biodiesel Model. 2014.

26. Y.B. Che Man, T. Haryati, H.M. Ghazali, B.A. Asbi, "Composition and thermal profile of crude palm oil and its products," Journal of the American oil chemists' society, 1999, vol. 76(2), pp. 237-242.

27. M. Berrios, J. Silec, M. A. Martin, A. Martin, "A kinetic study of the esterification of free fatty acids (FFA) in sunflower oil, Fuel, 2007, 86(15), pp. 2383-2388.

28. A. A. Newman, L. V. Cocks, "Glycerol," 1968: CRC Press.

29. J. Goodrum, "Volatility and boiling points of biodiesel from vegetable oils and tallow," Biomass and Bioenergy, 2002, vol. 22(3) pp. 205-211. 